\title{
STIPE ANATOMICAL STUDIES ON SELECTED PTERIDOPHYTES OF SOUTH INDIA
}

\author{
S. Resmi ${ }^{1}$, V. P. Thomas ${ }^{2}$ and V. K. SReenivas ${ }^{3}$ \\ ${ }^{1}$ Department of Botany, Calicut University, Malappuram, Kerala-673 635, India \\ ${ }^{2}$ Department of Botany, Catholicate College, Pathanamthitta, Kerala-689 645, India \\ E-mail:amomum@gmail.com \\ ${ }^{3}$ Department of Botany, Sree Vyasa NSS College, Wadakkencherry, Kerala-680 623, India
}

(Received 12 October, 2015; Accepted 29 December, 2015)

\begin{abstract}
Present study is based on the stipe anatomy of 13 selected species of pteridophytes of South India. Detailed description, key to the taxa based on stipe anatomy, photographs and descriptions are provided.
\end{abstract}

Key words: anatomy, pteridophytes, South India, stipe

\section{INTRODUCTION}

Pteridophytes are the second largest group of vascular plants with more than 10,000 extant species and having amazing level of diversity. More than 1,200 species of ferns are ever reported from India (Chandra 2000, Dixit 1984). Recently, Chandra et al. (2008) has revised the list and estimated it to contain about $900-1,000$ species. Fern taxonomists have long employed the characteristics of the rhizome, indusium, sporangia and spores in construction of the systematic treatments of various taxa. Stipe characters have proved to be of great value on the identity of a taxon (Lucansky and White 1974, Srivastava 2008a, $b$, Wagner 1997, Walker 1957, 1960). Other important works on the anatomy of pteridophytes are Bir (1977), Bir and Devi (1971), Paulillo (1963), and Stokey (1909). However, the characteristics of the stipe still remain to be studied in the case of a number of fern species. Stipes of 13 species of pteridophytes common on mid-lands of South India were studied to understand the anatomical features.

\section{MATERIALS AND METHODS}

The present study is based on the collections of specimens from various localities of South India. The stipe of the plant was preserved in polyvi- 
nyl chloride (PVC) bottles with formalin-acetic acid-alcohol (FAA) for further studies. Anatomical features were described from the transverse sections of stipe and key to species was also prepared to the selected taxa under investigation. The taxa studied were Drynaria quercifolia (L.) J. Sm., Christella dentata (Forssk.) Brownsey et Jermy, Pityrogramma calomelanos (L.) Link, Marsilea minuta L., Ceratopteris thalictroides (L.) Brongn., Lygodium flexuosum (L.) Sw., Adiantum latifolium Lam., A. caudatum L., A. philippense L., Parahemionitis cordata (Roxb. ex Hook. et Grev.) Fraser-Jenk., Pteris confusa T. G. Walker, P. vittata L. and P. pellucida Presl.

\section{RESULTS}

Key to the species based on stipe anatomy

1a The vascular strands $4-12$ receive by the stipe

Drynaria quercifolia

1b The vascular strands $1-2$ receive by the stipe

2a The stipe receives 2 vascular strands at the base and later unites to form a single vascular strand towards the apex

$2 \mathrm{~b}$ The stipe receives single vascular strand

3a The xylem is mesarch

Christella dentata

$3 \mathrm{~b}$ The xylem is diarch Pityrogramma calomelanos

4a Ground tissue is differentiated into outer aerenchymatous region

Marsilea minuta

4b Ground tissue is not differentiated into aerenchymatous region

5a The entire ground tissue is formed of loosely arranged parenchymatous cells

Ceratopteris thalictroides

$5 \mathrm{~b}$ The ground tissue is differentiated into outer sclerenchymatous and inner parenchymatous layers

6a Xylem is triarch 7

6b Xylem is not triarch

7a The xylem is arranged in a ' $\mathrm{T}$ '-shaped manner

Lygodium flexuosum

$7 \mathrm{~b}$ The xylem is arranged like a 'bison skull'

Adiantum latifolium

8a Xylem elements are arranged in exarch pattern

$8 \mathrm{~b}$ Xylem elements are arranged in mesarch pattern 
9a The vascular strand with semilunar shaped xylem

A. caudatum

$9 \mathrm{~b}$ Single trace of xylem in a vascular strand

10a The arrangement of xylem is $\mathrm{V}$-shaped with curved ends

A. philippense

$10 \mathrm{~b}$ The arrangement of xylem is V-shaped with straight ends Parahemionitis cordata

11a Xylem is arranged in a ' $\Omega$ '-shaped manner

Pteris confusa

$11 \mathrm{~b}$ Xylem is arranged in a V-shaped manner

12a Vascular strand is C-shaped P.vittata

$12 \mathrm{~b}$ Vascular strand is V-shaped

P. pellucida

\section{DESCRIPTIONS}

\section{Adiantum caudatum L.}

The transverse section of the stipe shows thick walled, single layered, dark brown outer epidermis with cuticle. Numerous long hairs are present on the epidermis. Epidermis is followed by ground tissue, which is differentiated into outer 3-4 layered sclerenchymatous cells and multilayered, thin walled, parenchymatous cells with rich tannin content. Vascular strand is seen at the centre and enclosed by a unilayered pericycle followed by a single layered, thick walled endodermis. The vascular strand represents two xylem groups; one is large, semi-lunar, diarch and exarch, another group forms small patch. The xylem is surrounded by the phloem (Fig. 1A).

\section{Adiantum philippense L.}

The outline of stipe is more or less circular and the outer epidermis is thick walled, dark brown, single layered with cuticle. The ground tissue is formed of outer 3-4 layered sclerenchymatous cells followed by thin walled parenchymatous cells with rich tannin content. Endodermis is single layered, formed of thick walled cells followed by a unilayered pericycle. The xylem is diarch, exarch and semi-lunar shaped. The metaxylem seen towards the centre and protoxylem arranged on the arms. The xylem is surrounded by the phloem (Fig. 1B).

\section{Adiantum latifolium Lam.}

Transverse section of petiole shows outer thick walled, single layered, cuticularised, brown coloured epidermis. Ground tissue is formed of outer 

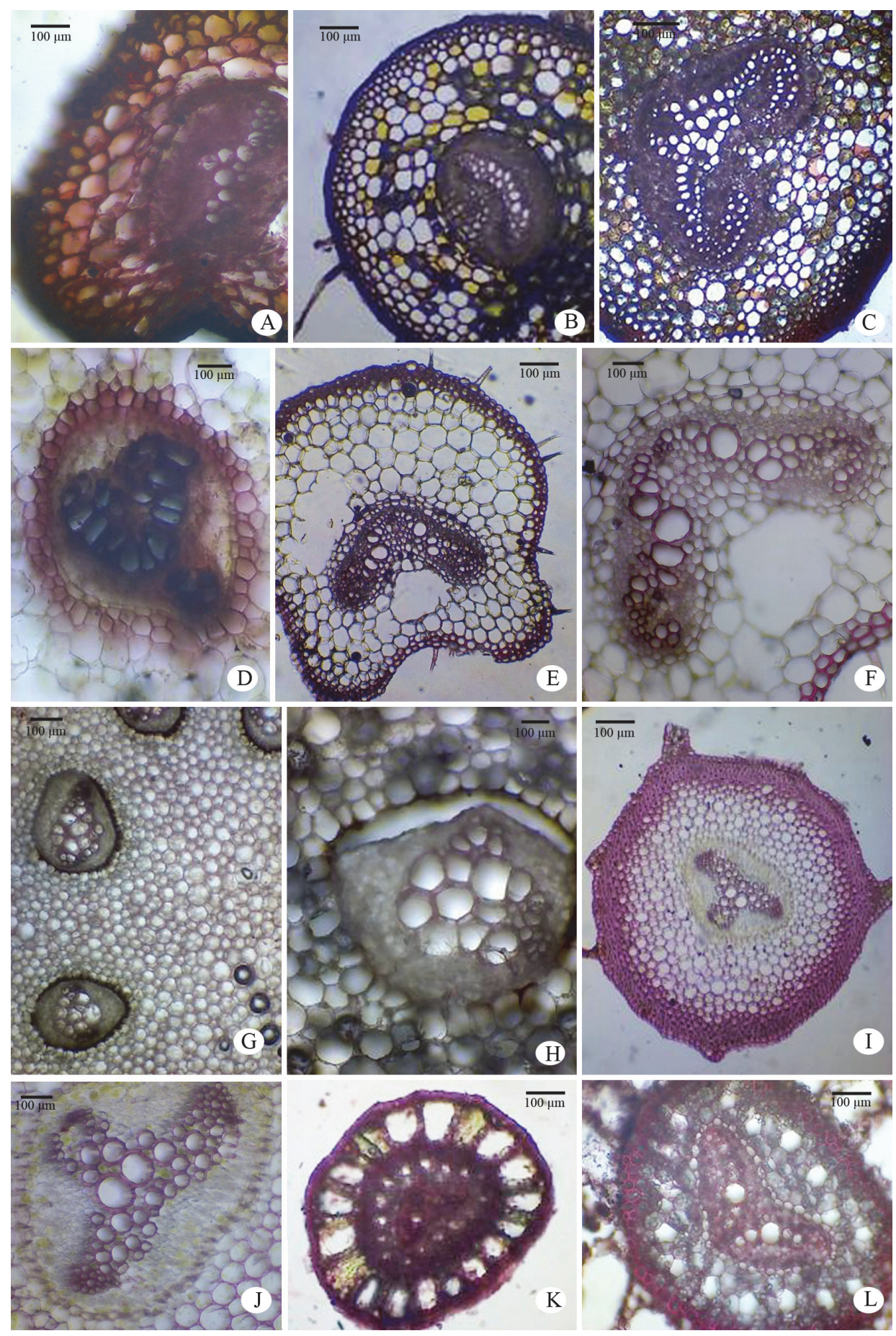
5-7 layered sclerenchymatous cells followed by inner 6-7 layered parenchymatous cells with tannin contents. The ground tissue is delimited by a single layered, thick walled endodermis followed by unilayered pericycle. Stipe receives a central vascular strand and the xylem is triarch and exarch. The xylem is arranged like the 'skull of a bison'; two groups of protoxylem are arranged near the 'horns' and one group at the base; metaxylem seen at the centre; xylem is surrounded by the phloem (Fig. 1C).

\section{Ceratopteris thalictroides (L.) Brongn.}

The stipe is more or less cylindrical in outline. The epidermis is single layered and thin walled. The ground tissue is formed of thin walled parenchymatous cells with intercellular spaces. The vascular strand is enclosed by 1-2 layered endodermis, which is formed of thick walled cells. The endodermis is followed by thin walled pericycle. Two xylem traces are observed in the stipe; the adaxial one is arranged in a V-shaped manner with curved ends and another small group formed of a few xylem elements. The xylem is surrounded by the phloem (Fig. 1D).

\section{Christella dentata (Forssk.) Brownsey et Jermy}

The epidermis is the outermost layer formed of small, dark brown, thick walled cells covered by smooth and delicate hairs. The ground tissue is multilayered, outer portion is formed of 2-3 layered sclerenchymatous cells followed by several layers of thin walled parenchymatous cells. Thin walled inner layers of cells usually have starch grains. The stipe receives two widely separated vascular strands from the rhizome. Later they fused together and become a single strand towards the apex. Each vascular strand is enclosed by a single layered endodermis (Fig. 1E). The pericycle is made up of thin walled cells, which are 1-3 layers in thickness. The xylem is mesarch and surrounded by phloem (Fig. 1F). The xylem is hippocampus-shaped. The adaxial arms are comparatively more turned inwards and the two vascular strands appear almost reniform in shape.

Fig. 1. Stipe anatomy of different species of pteridophytes. A = Adiantum caudatum, a portion of transverse section of stipe showing vascular strand and ground tissue. $\mathrm{B}=$ Adiantum philippense, transverse section of stipe. $\mathrm{C}=$ Adiantum latifolium, transverse section of stipe showing vascular strand. $\mathrm{D}=$ Ceratopteris thalictroides, vascular strands. $\mathrm{E}=$ Christella dentata, transverse section of stipe. $\mathrm{F}=$ Christella dentata, vascular strand enlarged. $\mathrm{G}=$ Drynaria quercifolia, a portion of transverse section of stipe. $\mathrm{H}=$ Drynaria quercifolia, single vascular strand enlarged. I = Lygodium flexuosum, transverse section of stipe. J = Lygodium flexuosum, vascular strand enlarged. $\mathrm{K}=$ Marsilea minuta, transverse section of petiole. $\mathrm{L}=$ Marsilea minuta, vascular strand enlarged 


\section{Drynaria quercifolia (L.) J. Sm.}

Transverse section of the stipe shows outer epidermis formed of small compactly packed cells, which are covered by cuticle. The ground tissue is many layered, outer sclerenchymatous (10-12 layered) and inner parenchymatous cells. The stipe receives 4-12 vascular strands from the rhizome. Four vascular strands are observed in young condition and 12 strands in matured stipe. Each vascular strand is surrounded by a single layered pericycle and endodermis. The xylem is exarch, which are irregular in shape and two groups of protoxylem are seen on either sides (Figs 1G-H).

\section{Lygodium flexuosum (L.) Sw.}

The transverse section shows outer single layered epidermis formed of compactly arranged rectangular shaped cells, which are cuticularised. The ground tissue is formed of outermost 5-6 layered sclerenchymatous cells followed by 4-5 layered thin walled parenchymatous cells (Fig. 1I). The vascular strand is enclosed by a single layered endodermis followed by a layer of pericycle formed of thin walled cells. The xylem is arranged in a T-shaped manner (Fig. 1J). The xylem is triarch and exarch. There are three groups of protoxylem facing towards the periphery and the metaxylem seen at the centre.

\section{Marsilea minuta L.}

Transverse section of petiole shows three distinct regions. The epidermis is single layered and the cells are rectangular in shape. The ground tissue is differentiated into outer aerenchyma having many air cavities separated by uniseriate parenchymatous trabeculae or septa. The middle region is made up of 2 layered sclerenchymatous cells. The inner region is parenchymatous with air spaces containing starch and tannin filled cells (Fig. 1K). The petiole receives a vascular strand from the rhizome and is delimited by a layer of endodermis followed by a unilayered pericycle. The xylem is arranged in a Vshaped arches. The two arms of each group come close to each other at their base. Each arm of V-containing metaxylem towards the centre, protoxylem towards the outer side and the xylem remain surrounded by phloem (Fig. 1L).

Parahemionitis cordata (Roxb. ex Hook. et Grev.) Fraser-Jenk.

The epidermis is the outermost layer, where the cells are small, thick and dark coloured. The outer wall of epidermal cells is cutinised and covered by hairs. Epidermis is followed by 4-5 layers of sclerenchymatous cells arranged without intercellular spaces. The inner ground tissue is $4-5$ layered, 
parenchymatous with intercellular spaces and some of the cells are with tannin content (Fig. 2A). Endodermis is single layered and consists of more or less rectangular shaped cells and is followed by a single layered pericycle, which is formed of thin walled cells. Vascular strand is seen at the centre and the xylem is diarch, arranged in a V-shaped manner (Fig. 2B). Metaxylem placed towards the centre and the protoxylem towards the periphery. The xylem remains surrounded by phloem.

\section{Pityrogramma calomelanos (L.) Link}

The transverse section of stipe shows outermost thick walled, single layered, compactly arranged, dark brown, epidermis surrounded by cuticle. Ground tissue is differentiated into outer thick walled 3-4 layered collenchymatous cells and inner thin walled 3-4 layered parenchymatous cells. The outer region is rich in tannin content. The stipe receives two vascular strands from rhizome and each vascular strand is surrounded by single layered endodermis formed of thin walled, elongated cells (Fig. 2C). The endodermis is followed by a single layered pericycle. Vascular strands are slightly elongated. The xylem is hippocampus-shaped; protoxylem directed towards outside (Fig. 2D). The xylem is surrounded by the phloem. The strands come in contact from the base towards centre and fused.

\section{Pteris confusa T. G. Walker}

The epidermis is formed of a single layer of parenchymatous cells covered with cuticle and ramentum scales. Ground tissue is seen below the epidermis, formed of 2 or 3 layers of sclerenchymatous cells; inner ground tissue is formed of 3-4 layers of parenchyma. The cells have tannin. A single vascular strand is seen at the centre. Vascular strand is surrounded by the pericycle and endodermis. The vascular strand is $\Omega$-shaped and the phloem surrounds the xylem. The xylem is mesarch. Phloem has parenchyma and sieve tubes (Fig. 2E).

\section{Pteris pellucida Presl.}

The transverse section of stipe shows outermost single layered epidermis, formed of parenchyma and covered with cuticle. Ground tissue is seen below the epidermis, formed of outer 2 or 3 layers of sclerenchymatous region followed by 3-4 layers of parenchyma; ground tissue shows the presence of chloroplast. A single vascular strand is surrounded by pericycle and endodermis. The vascular strand is V-shaped and the phloem surrounds the xylem. The xylem is mesarch and arranged in a V-shaped manner (Fig. 2F). 


\section{Pteris vittata L.}

The outline of stipe is cordate. The epidermis is formed of single layered parenchymatous cells covered with cuticle and ramentum scales. The ground
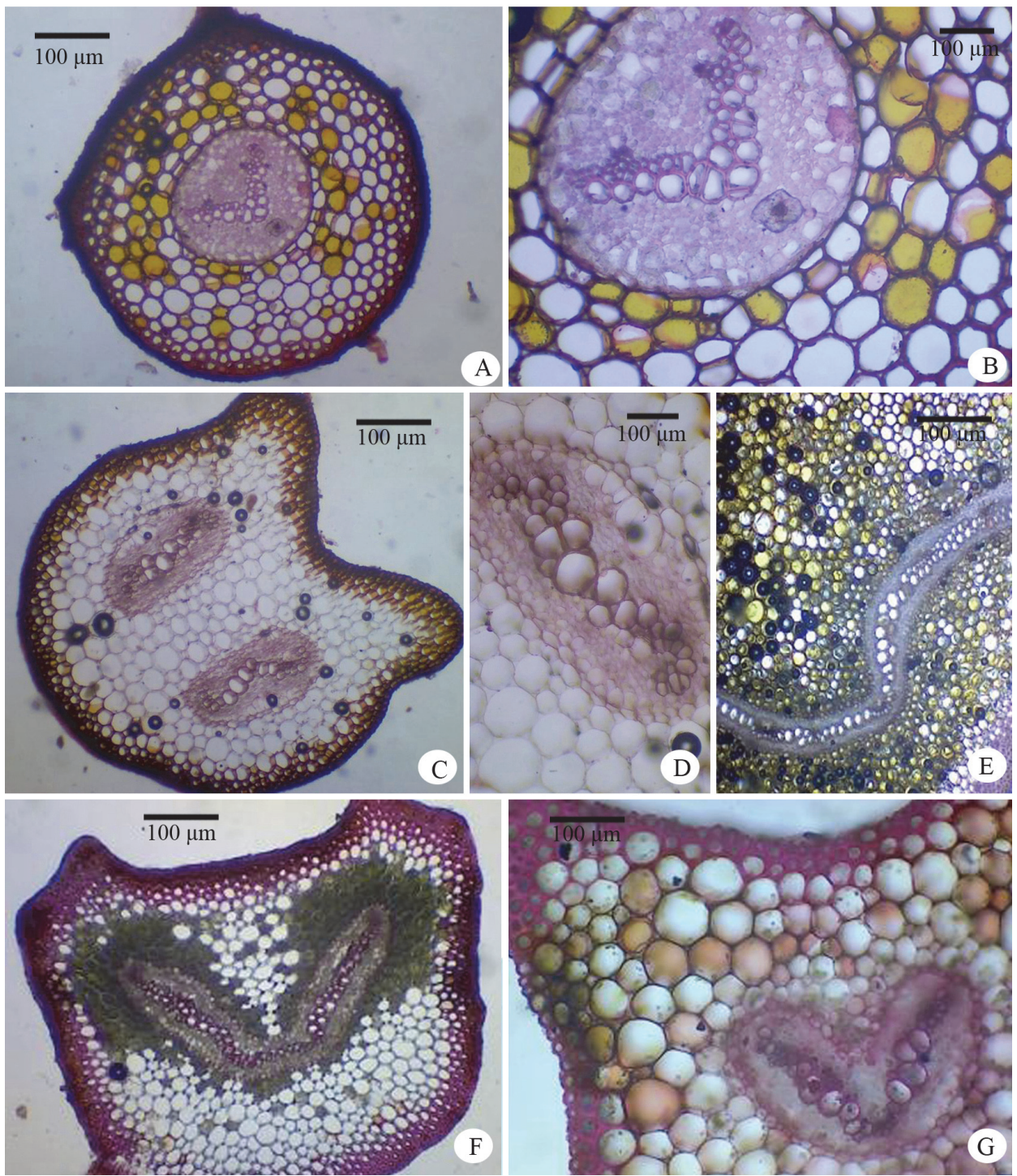

Fig. 2. Stipe anatomy of different species of pteridophytes. A = Parahemionitis cordata, transverse section of stipe. $\mathrm{B}=$ Parahemionitis cordata, vascular strand enlarged. $\mathrm{C}=$ Pityrogramma calomelanos, transverse section of stipe. $\mathrm{D}=$ Pityrogramma calomelanos, vascular strand enlarged. $\mathrm{E}=$ Pteris confusa, a portion of transverse section of stipe. $\mathrm{F}=$ Pteris pellucida, transverse section of stipe. $\mathrm{G}=$ Pteris vittata, a portion of transverse section of stipe 
tissue is formed of outer sclerenchymatous cells and inner 3-4 layered parenchyma cells. Tannin cells are present. Vascular strand is horse-shoe shaped or $\mathrm{C}$-shaped. The vascular strand surrounded by endodermis followed by the pericycle. The xylem is mesarch and arranged in V-shaped manner and the phloem surrounds the xylem. The xylem has protoxylem points directed towards the adaxial side (Fig. 2G).

\section{DISCUSSION}

Stipe anatomical features were reported to be suitable for the systematic study of ferns because of the variations in shape of steles and the presence of special tissues like sclerenchyma (Bidin and Anita 1995, Masturi 1996, Ogura 1972, White 1984). Each species is proved to have distinct stipe anatomical characteristics and hence that can be used to separate different species. Problems in species identification due to the similarities in morphological characteristics could be solved using anatomical characteristics.

Cuticle is present in almost all species of plants under investigation. Presence of well-developed cuticle is an adaptation to terrestrial habitat. Ferns would be more vulnerable to desiccation if it was not for the presence of a water barrier in the form of an external coating. Cuticle contains hydrophobic materials, secreted by the epidermal cells and forms an almost continuous coating over the entire outer surface of ferns.

In all species under study, transverse section of stipe shows a many layered ground tissue. The ground tissue of Adiantum caudatum, A. latifolium, A. philippense, Christella dentata, Drynaria quercifolia, Lygodium flexuosum, Parahemionitis cordata, Pteris confusa, P. pellucida and P. vittata is differentiated into outer sclerenchymatous and inner parenchymatous regions. In Ceratopteris thalictroides, the ground tissue is formed of many layered parenchyma cells. This may be due to the adaptation of the species to survive in aquatic habitat. In Marsilea minuta, sclerenchymatous middle cortex is present contrary to others. Collenchymatous outer region and parenchymatous inner cortex is seen in Pityrogramma calomelanos. Tannin cells are clearly seen in the ground tissue of Adiantum caudatum, A. latifolium, A. philippense, Marsilea minuta, Parahemionitis cordata, Pityrogramma calomelanos, Pteris confusa and $P$. vittata. In Pteris pellucida inner parenchymatous ground tissue is chlorophyllated.

The xylem is arranged in a hippocampus-shaped manner in Christella dentata and Pityrogramma calomelanos. In Marsilea minuta, Pteris pellucida, P. vittata, Parahemionitis cordata, Ceratopteris thalictroides and Adiantum philippense the xylem is arranged in a V-shaped manner. In Adiantum caudatum it is semilunar-shaped and in Lygodium flexuosum, xylem is arranged in a T-shaped manner. In Adiantum latifolium xylem is arranged like the skull of a bison, where as in $P$. confusa it is arranged in a $\Omega$-shaped manner. 
The stipe of Christella dentata and Pityrogramma calomelanos receives two vascular strands from the rhizome, later they fuse together to form single strand towards apex. Parahemionitis cordata receives 4-12 vascular strands from the rhizome. Since the plant is an epiphytic form, the feature may be an adaptation to cope with the habitat.

Plants provide an orderly and comprehensive array of curiosities for their identification and categorisation and anatomical features are one of the important criteria for the identification of the pteridophytes.

\section{REFERENCES}

Bidin, A. A. and Anita, S. (1995): The stipe anatomy of the fern genus Adiantum L. from Peninsular Malaysia. - Malay. Appl. Biol. 24(2): 57-69.

Bir, S. S. (1977): Anatomy of pteridophytes. - In: Padhi, B. (ed.): Frontiers of plant sciences. Prof. P. Parija Felic. Comm., Bhubaneswar, Orissa, pp. 365-400.

Bir, S. S. and Devi, K. (1971): Anatomical observations on the Indian species of genus Vittaria J. Sm. - Proc. Indian Natl. Sci. Acad. 37: 31-45.

Chandra, S. (2000): The ferns of India. - International Book Distributors, Dehra Dun.

Chandra, S., Fraser-Jenkins, C. R., Kumari, A. and Srivasthava, A. (2008): A summary of the status of threatened pteridophytes of India. - Taiwania 53: 170-209.

Dixit, R. D. (1984): A census of the Indian pteridophytes. - Flora of India, ser. 5. Botanical Survey of India, Howrah.

Lucansky, T. W. and White, R. A. (1974): Comparative studies of the nodal and vascular anatomy in the neotropical Cyatheaceae, 3. Nodal and petiole patterns; summary and conclusions. - Amer. J. Bot. 61: 818-828. http://dx.doi.org/10.2307/2441618

Masturi, A. (1996): Anatomical variations and spore ultrastructures of Malaysian grass ferns: Schizaea digitata (Linn.) Sw. and Schizaea dichotoma. - J. Sm. Malay. Appl. Biol. 25: 69-74.

Ogura, Y. O. (1972): Comparative anatomy of the vegetative organs of the pteridophytes. - Gebrüder Borntraeger, Berlin, Stuttgart.

Paulillo, D. J. (1963): The developmental anatomy of Isoetes. - Illinois Biol. Mon. No. 31, Univ. 1llinois Press.

Stokey, A. G. (1909): The anatomy of Isoetes. - Bot. Gaz. 47: 311-335. http://dx.doi. org/10.1086/329874

Srivastava, K. (2008a): The petiolar structure of Christella dentata (Forssk.) Brownsey et Jermy (Thelypteridaceae, Pteridophyta). - Ethnobot. Leafl. 12: 96-102.

Srivastava, K. (2008b): Epidermal features and petiolar anatomy of Angiopteris evecta (Forst.) Hoffm. (Marattiaceae: Pteridophyta). - Ethnobot. Leafl. 12: 139-149.

Wagner, G. M. (1997): Azolla: a review of its biology and utilization. - Bot. Review 63: 1-26. http://dx.doi.org/10.1007/bf02857915

Walker, T. G. (1957): Idiopteris, a new genus of fern from Ceylon. - Kew Bull. 12: 429-432. http://dx.doi.org/10.2307/4113719

Walker, T. G. (1960): The Pteris quadriaurita complex in Ceylon. - Kew Bull. 14: 321-333. http://dx.doi.org/10.2307/4114745

White, R. A. (1984): Comparative development of vascular tissue patterns on the shoot apex of ferns. - In: White, R. A. and Dickison, W. C. (eds): Contemporary problems in plant anatomy. Academic Press, New York. 